\title{
GIS Stewardship Survey Report
}
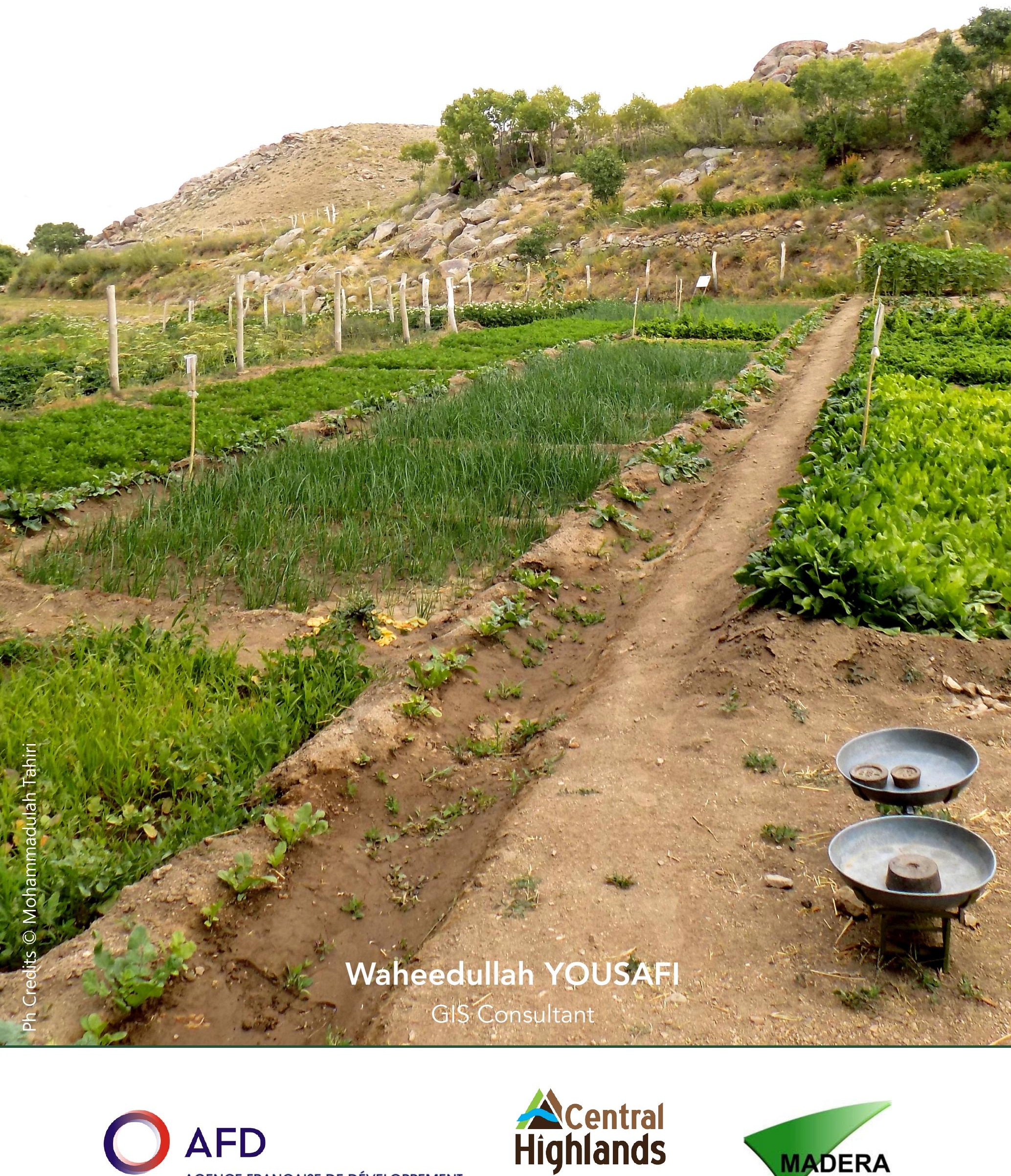


\section{AFD Highlands \\ Sustainable Development Programme}

Central Highlands Programme (CHP) is common initiative implemented by a consortium of three French NGOs (GERES, MADERA and SOLIDARITES INTERNATIONAL) funder by the Agency for French Development (AFD). The general objective of the programme is to increase the living standards and quality of life of rural mountainous populations by promoting balanced rural development and preservation of natural resources. The 3.5 years programme was launched in March 2014 in two provinces of the Central Afghanistan: Bamyan and Maydan-Wardak.

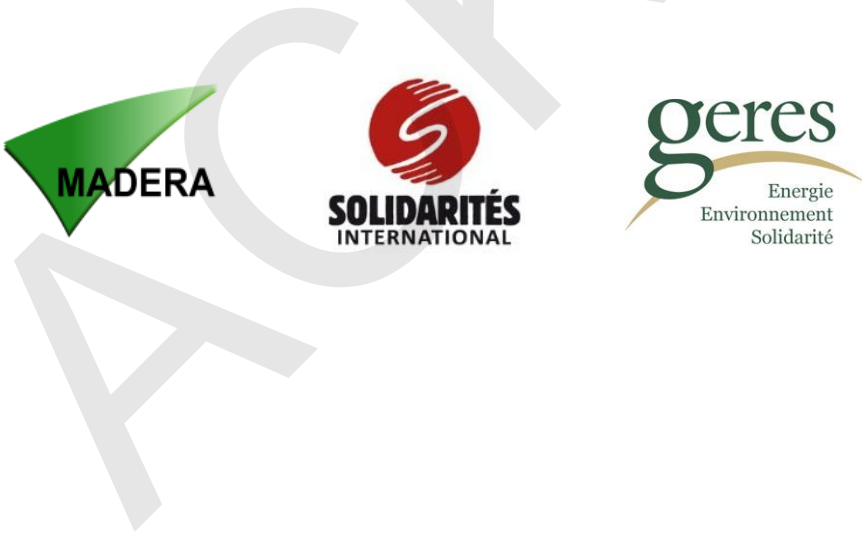

(C) 2017 The Agency for French Development (AFD), Kabul, Afghanistan.

This report was prepared by independent consultants contracted by implementing partners on behalf of AFD. The views and opinions in this report do not necessarily reflect the views and options of AFD or the implementing partner. 


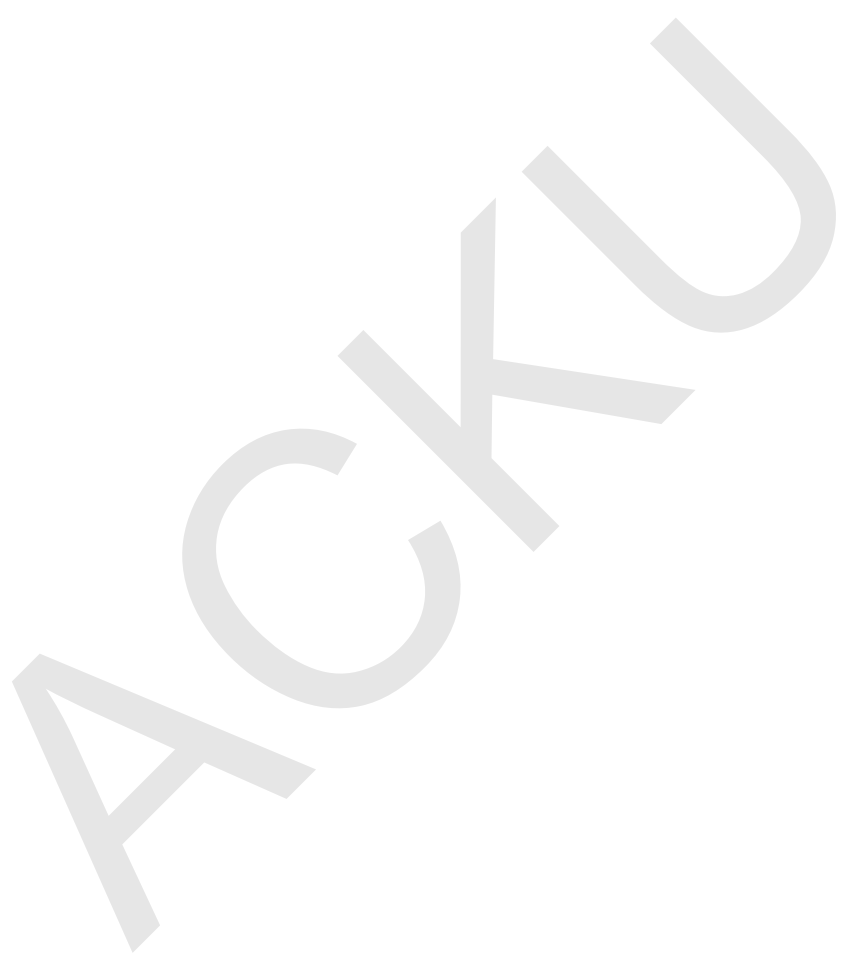




\section{Contents}

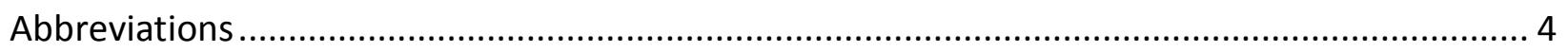

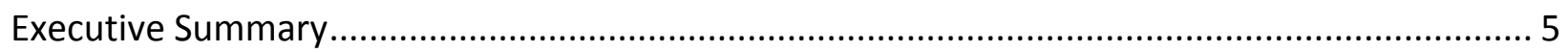

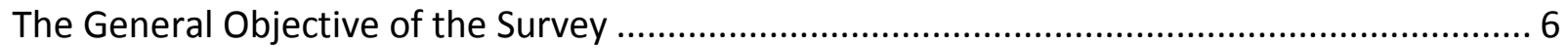

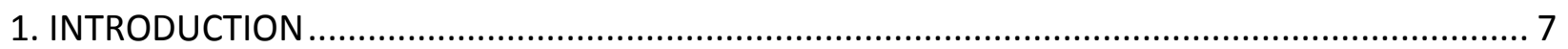

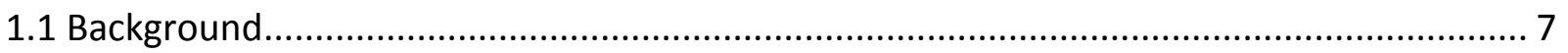

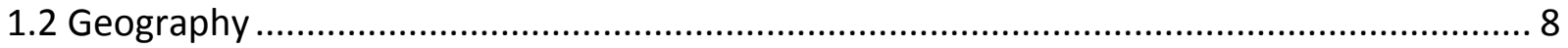

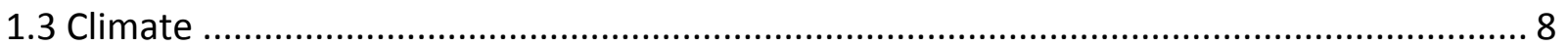

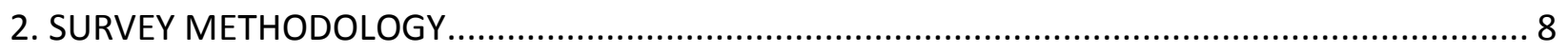

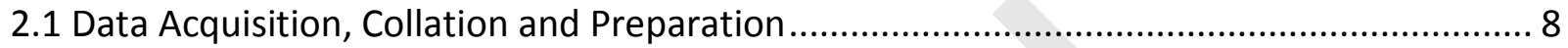

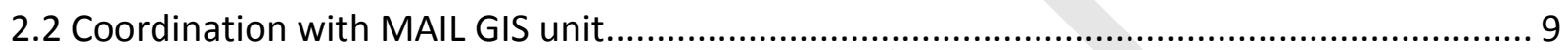

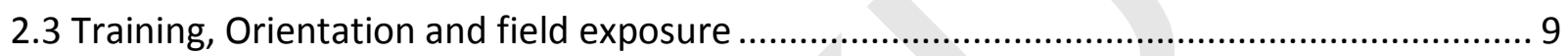

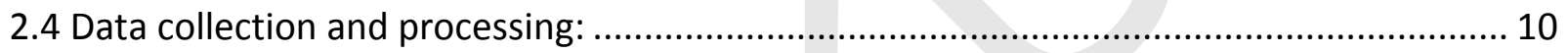

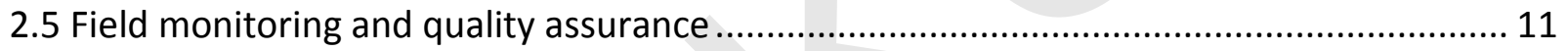

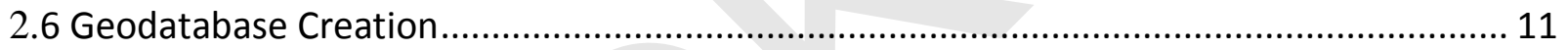

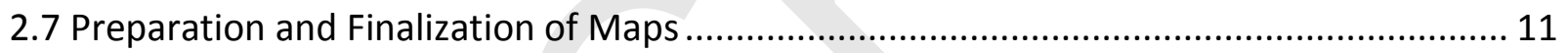

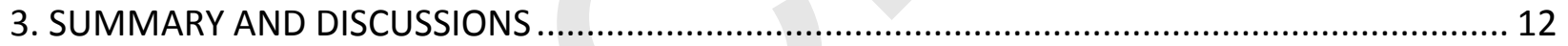

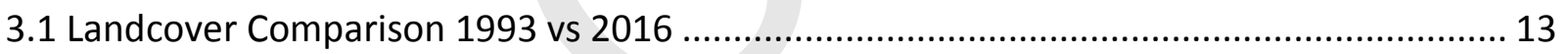

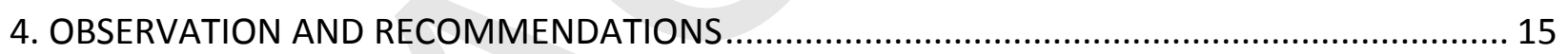

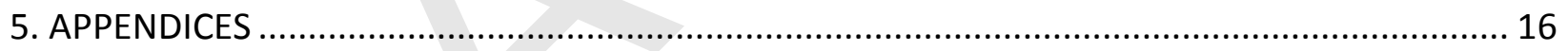

Appendix I: Amount of irrigated area and no of teams for each district................................ 16

Appendix II: Irrigation Field Survey Questionnaire (Dari) ......................................................... 16

Appendix III: Wheat deficit and surplus provinces of Afghanistan .......................................... 17

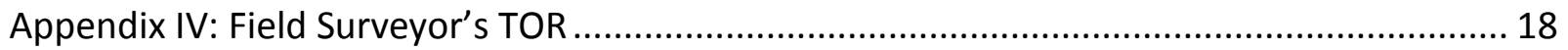

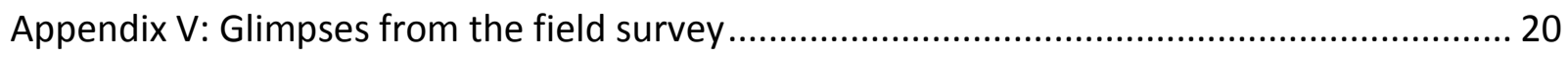

Appendix VI: Wheat per capita consumption of Afghanistan and other regional countries ... 22

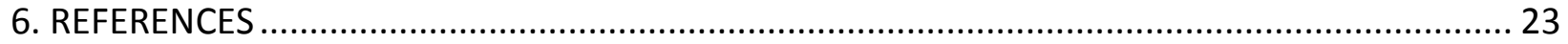




\section{Abbreviations}

GIS Geographic Information System

RS Remote Sensing

GPS Global Positioning System

AGCHO Afghanistan Geodesy and Cartography Head Office

CSO Central Statistics Office

LCA Landcover Atlas

MAIL Ministry of Agriculture, Irrigation and Livestock

AREU Afghanistan Research and Evaluation Unit

MEW Ministry of Energy and Water

NEPA National Environmental Protection Agency

MADERA Mission d'Aide au Développement des Economies Rurales

Solidarite Solidarités International

GERES Group for Environment, Renewable Energy and Solidarity

APR Agricultural Prospect Report

FEWS NET Famine Early Warning Systems Network

DEM Digital Elevation Model

Topo Maps Topographic Maps of Afghanistan

IPC Integrated Food Security Phase Classification

MT Metric Ton

UNFAO Food and Agricultural Organization of the United Nations 


\section{Executive Summary}

This report describes an assessment and findings on natural resource management in the three districts namely Behsud I and II and Yakawlang of Maidan-Wardak and Bamyan provinces respectively. The survey aimed at producing relevant knowledge through a detailed survey for producing GIS maps of the existing irrigation and watershed systems and infrastructure in the project areas, to be used in the program in order to ensure improved management of water resources, and to be disseminated to institutional stakeholders, NGOs and actors involved in designing and implementing the Provincial Development Plan.

Agriculture is the most important source of income for the households of the mentioned districts. In addition, these districts are predominantly rural in nature thus the development of rural areas is key to the development of the region. In turn, the development of rural area is not possible without developing the agricultural sector and water is vital for both irrigated and rainfed agriculture in the area.

The terrain of the area is mountainous with very little arable land available for cultivation mostly in the narrow valleys. The population relies primarily upon subsistence farming with irrigated and rain-fed wheat, barley and potato being the main crops grown, supplemented with small scale livestock rearing. Agriculture productivity is low, estimated as 1.89 and 2.08 ton/ha for irrigated wheat and 0.54 and 0.97 ton/ha for rainfed wheat in Bamyan and Maidan-Wardak provinces (APR 2016), with limited access of the population to certified seed, latest technology in the field and irrigation water.

During the survey 1035 canals were identified in the mentioned three districts, however, 853 of them (82.5\%) have been surveyed. The remaining canals were not surveyed due to inaccessibility and security as advised by MADERA field office.

Less than $50 \%$ of the population has access to land and this limits their ability to grow adequate food for their own consumption. Non-agricultural capabilities are very limited, which makes income diversification to other commercial activities difficult on the short run. Both MaidanWardak and Bamyan provinces are wheat deficient based on the wheat per capita of 162 $\mathrm{kg} / \mathrm{head} /$ year and a total population of 606,000 and 455,000 for year 2016 . Furthermore, the comparison of landcover data from 2016 and 1993 shows increase in irrigated/ rainfed lands, while it shows decrease in barren and rangelands which are vital for livestock rearing communities. Marshes and water bodies also shrunk during the past twenty years based on the comparison.

In addition, land, water and vegetation of mentioned districts have been vital livelihood resources for local upland dwellers and nomadic pastoral communities for generations. Bamyan has plenty of water resources, it can suffice the irrigation needs of not only Bamyan province but other neighboring provinces if properly managed and there are many opportunities for agricultural improvement in the fields of animal husbandry, pasture improvement, agricultural productivity, watershed management and irrigation system improvement.

Therefore, the extracted information through this GIS stewardship survey can be used for planning of the rural communities within these districts. 


\section{The General Objective of the Survey}

The survey aims at producing relevant knowledge through a detailed survey for producing GIS maps of the existing irrigation and watershed systems and infrastructure in the program areas, to be used in the program in order to ensure improved management of water resources, and to be disseminated to institutional stakeholders, NGOs and actors involved in designing and implementing the Provincial Development Plan. 


\section{INTRODUCTION}

\subsection{Background}

MADERA, GERES and Solidarités International, three French NGOs working in Afghanistan, have come together to implement a 3.5 year program, funded by the French development agency (AFD). The aim of the program is to increase the living standards and quality of life for the rural population of the Central Highlands region, through the promotion of rural development and natural resources management.

The three districts of the two provinces selected for GIS stewardship survey belong to the central provinces of Afghanistan (Map 1). The central highland region is isolated, mountainous region of the country where majority of the population are farmers whose livelihood mainly depend on available natural resources especially land and water. However due to harsh climate in the region, combined with over exploitation of the land a substantial burden is being placed on already scarce natural resources, which necessitates finding sustainable solutions for frequent landuse conflicts and degradation of these resources (Comparison, table 2). The two provinces namely Bamyan and Maidan-Wardak, are located on an average altitude of about 3000m and in central mountainous agro-pastoral livelihood zone. They are severely affected by prolonged winter with heavy snowfalls which hinders coping mechanisms by limiting livelihood options, new practices and overall economic development of the rural people.

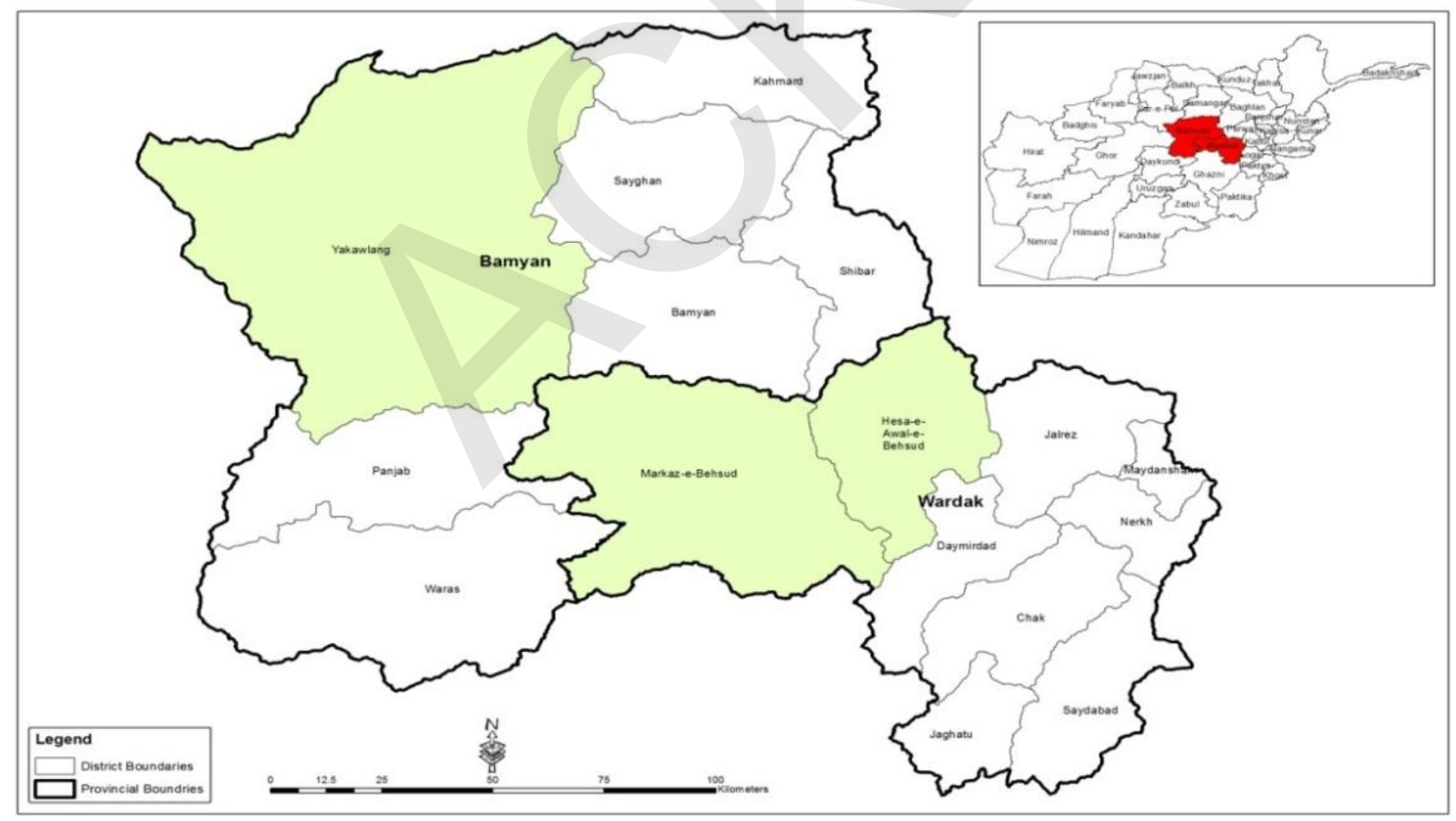

Figure 1: location map of target districts 
According to the Central Statistics Organization (CSO) Wardak and Bamyan provinces has 606,077 and 454,633 population respectively. However the individual district level population is 90,747 persons in Yakawlang and 123,801 and 38,421 persons in Behsud II and I districts respectively.

Most of the population lives in rural areas where agriculture is the main source of income. The terrain is extremely mountainous with very little arable land available for cultivation. The population relies primarily upon subsistence farming with irrigated/rain-fed wheat and barley and potato being the main crops grown, supplemented with small scale livestock rearing. Agriculture productivity is low, with limited access of the population to seeds, technology and irrigation water.

Moreover, nonagricultural capabilities are very limited, which makes income diversification to other commercial activities difficult on the short run. There are high levels of unemployment and underemployment which contribute to increased food insecurity and growing poverty (food outlook 2016).

\subsection{Geography}

Bamyan and Maidan Wardak provinces are located in the central and eastern regions of Afghanistan respectively; bordering Baghland and Parwan to the north east, Wardak and Ghazni to the southeast, Daykundi to the southwest, Ghor to the west, Saripul in the northwest and Samangan to the north while Wardak borders, Kabul and Logar to the east, Ghazni to the south and Bamyan to the west. They are mountainous with plains and many valleys. The majority of its residents live in rural areas, with villages concentrated in areas with available irrigation and water resources.

\subsection{Climate}

Bamyan's and Maidan-Wardak climate is transitional between cold arid and semi-arid, with cold winters and warm, dry summers. Precipitation mostly falls in late winter and spring (from October to May). The province is characterized by a dry, mountainous climate, with a high propensity for microclimates within the numerous steep valleys.

\section{SURVEY METHODOLOGY}

\subsection{Data Acquisition, Collation and Preparation}

First phase of the survey commenced with utilization of GIS/RS technology. First all firsthand satellite data was collected, collated and prepared for analysis in ArcGIS software.

All the data required for this analysis was geo-referenced and suitable Image enhancements were applied to facilitate the delineation and interpretation of different thematic information at the mentioned districts/catchments. 


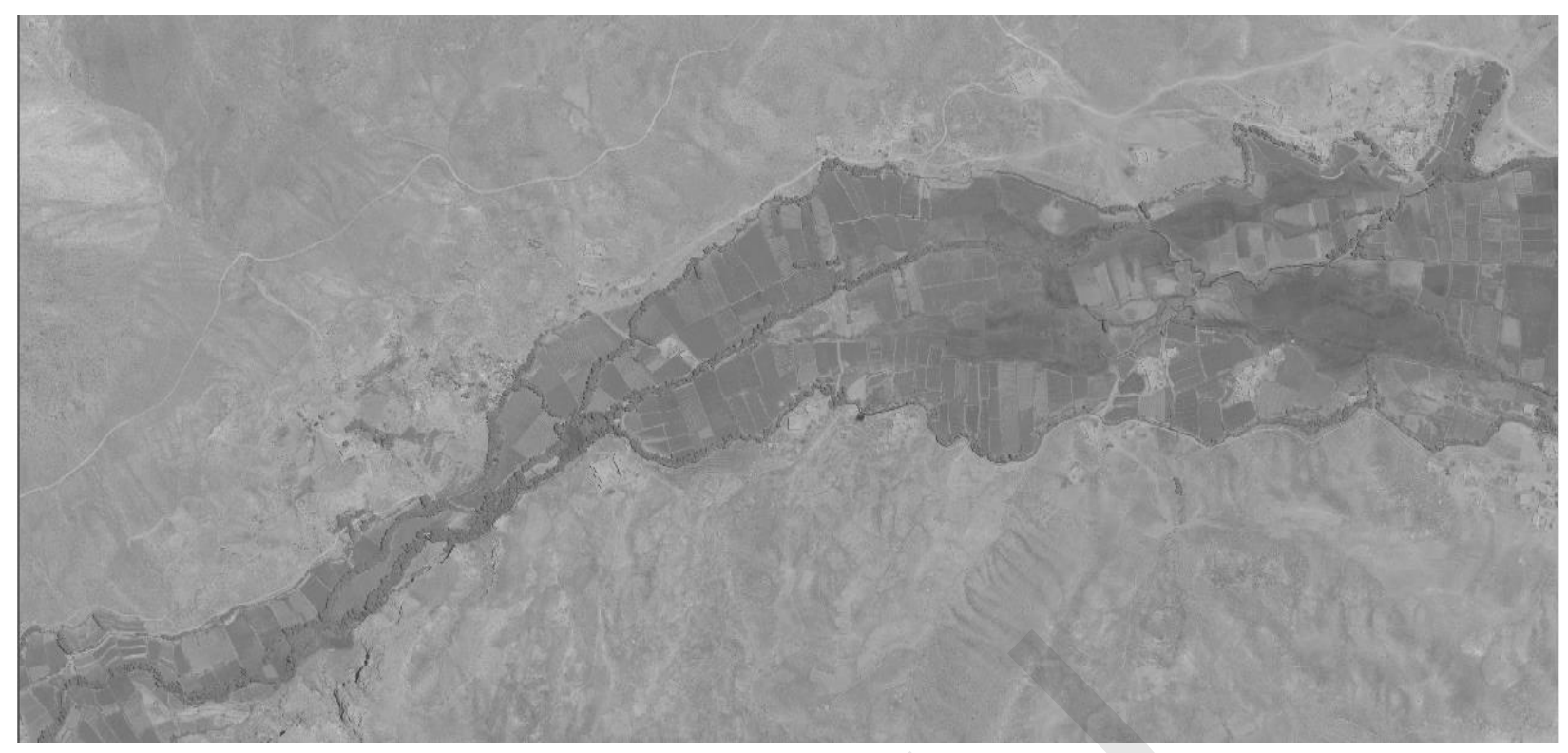

Figure 2: Sample satellite image used for this survey

As an input to the ArcGIS software, latest $50 \mathrm{~cm}$ and $1 \mathrm{~m}$ resolution cloud free satellite imagery, 1:50,000 topo sheets, $30 \mathrm{~m}$ resolution DEM and field survey data were used for identification, delineation, enrichment and mapping of canals and their respective command areas. In addition, latest available landcover data e.g. forest, rangeland, fruit trees, rainfed and irrigated land were derived from landcover Atlas of Afghanistan MAIL, 2016 and were enriched with data from this survey.

\subsection{Coordination with MAIL GIS unit}

All activities of the survey right from designing the questionnaire to the actual survey and the database creation was shared and consulted with MAIL GIS unit to ensure harmonization of both data and its attributes with the database already existing in MAIL GIS unit for national irrigation systems.

\subsection{Training, Orientation and field exposure}

Before the survey started, a two day survey orientation, in close consultation of Bamyan University and the consortium, was arranged in Bamyan province for the recruited surveyors and their respective supervisors. The surveyors were students of geoscience faculty of Bamyan University. There were 10 survey teams with six supervisors for these teams. Number of survey teams and supervisors were selected based on the total agricultural land of the respective district (Appendix I), accessibility and topography of the area. On the second day of the orientation the teams were taken to Bamyan city and showed them how to use the prepared map for each canal and collect the data using the pre-designed questionnaire. The questionnaire (Appendix II) was designed to collect all the data that was not possible to be extracted from the satellite imagery.

After the orientation the teams were sent to their respective districts along with prepared maps of the identified canals. 

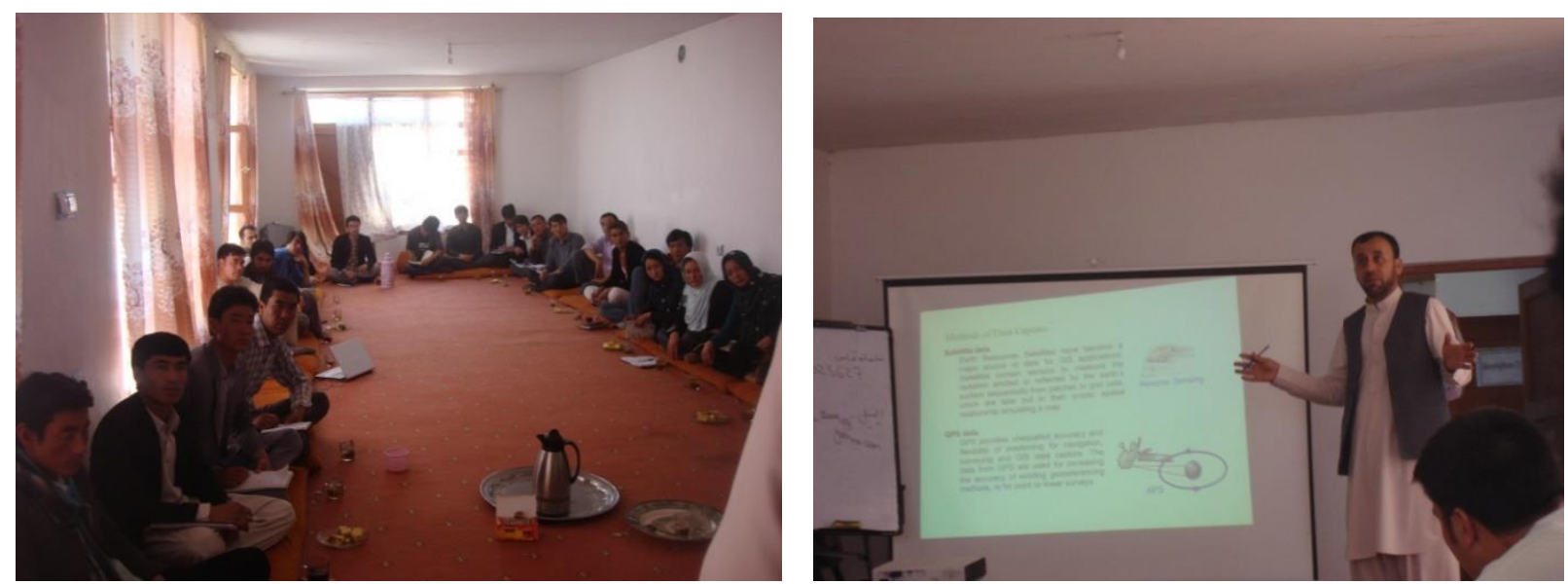

Figure 3: Glimpses from the orientation training for field surveyors and supervisors

Each survey team consisted of two members and every two teams had one supervisor to oversee their daily work and propose on time corrective measures whenever required. Each team was supposed to survey certain number of irrigation canals and hand over their forms or survey data to the supervisor at the end of each day

\subsection{Data collection and processing:}

Three types of field maps (figure: 4) were prepared i.e. two index maps (small scale maps) while one individual canal map (large scale map) with villages also drawn on all of them for easy identification of the canals in the field. Once the canal was identified in the field, using the village and other available data on the map, they were surveyed for data collection on each canal using the pre-designed questionnaire. The index maps were used to locate the location of the canal and also to find out the area in which the survey team was doing his survey.

Field data collection (field survey) was closely communicated with MADERA field offices and other sister organizations operating in the areas for safety and better implementation, however, some small patches (areas) were not surveyed due to inaccessibility to the sites and in some cases due to security concerns.

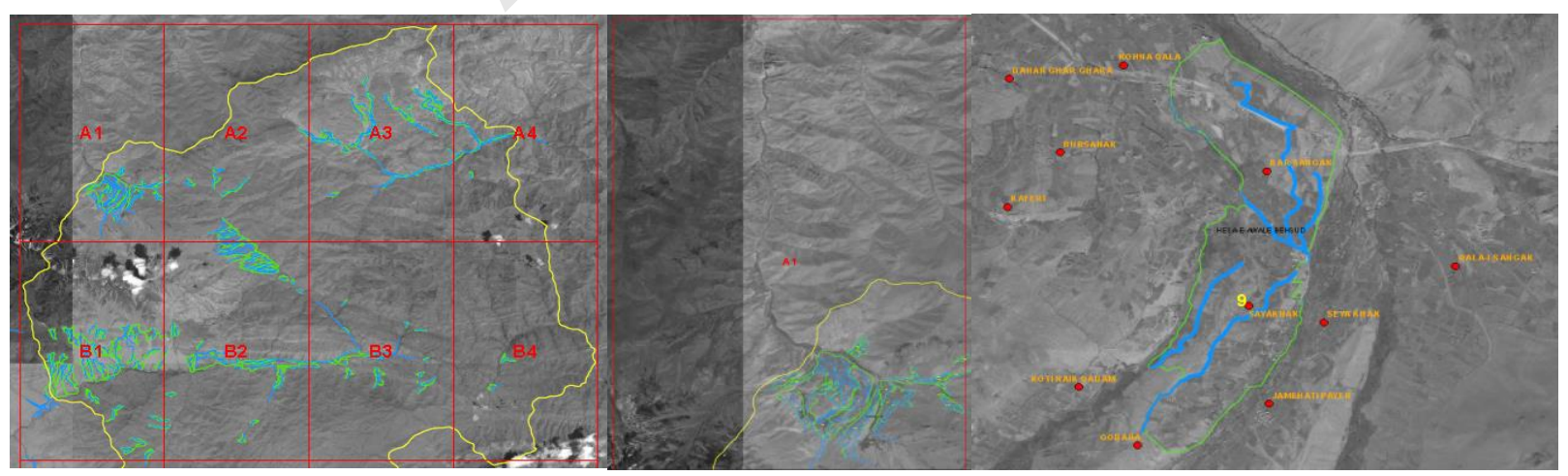

Figure 4: 3 types of maps prepared for field surveyors and supervisors 


\subsection{Field monitoring and quality assurance}

Each survey team consisted of two members and one supervisor was available to oversee their daily work and propose on time corrective measures whenever required. The supervisor was responsible for assuring the quality of survey and data collection on daily basis. If there was an issue with data he had to send back the team and recollect the data where required.

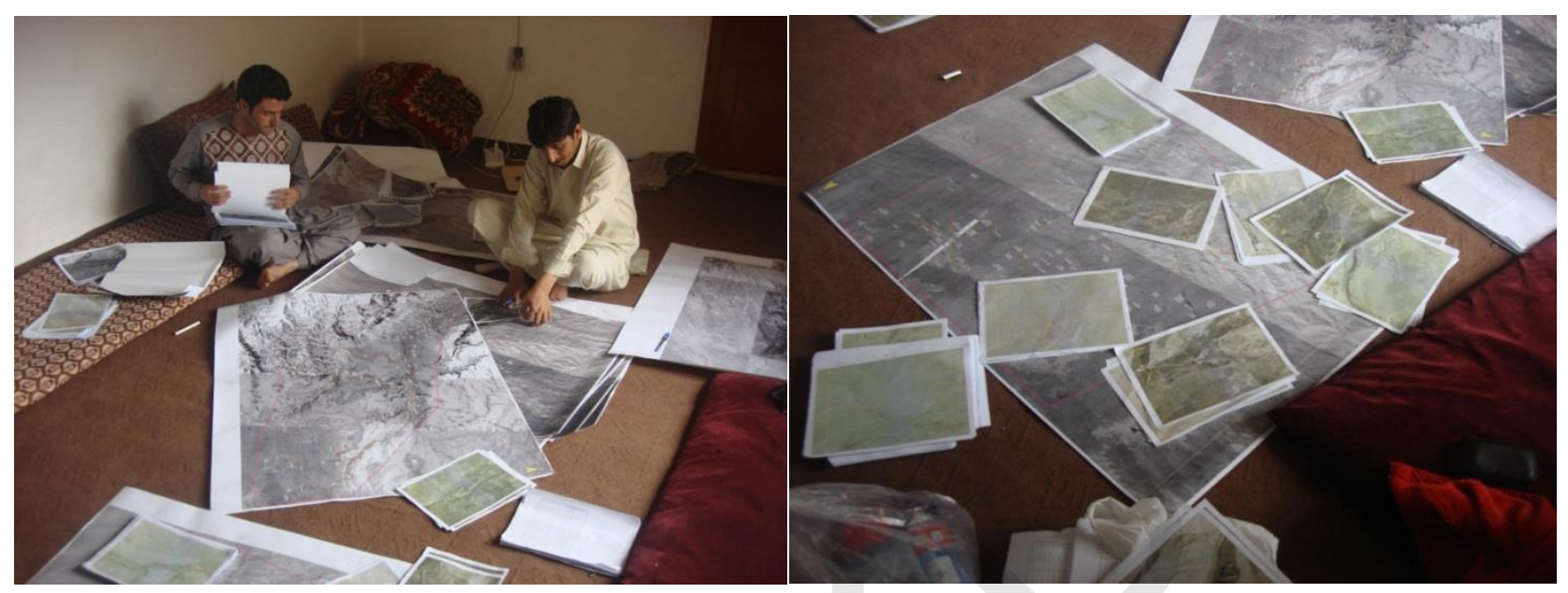

Figure 5: Field data checking and preparing for next missions

\subsection{Geodatabase Creation}

A geodatabase was created for each district and a combined geodatabase for all the three districts of the two provinces and all the data related to irrigation canals, their command areas, length, village names, headwork type (stone masonry, concrete etc), source of water (spring, karez, nawur, river etc) and the name of mirab were all put into this database for future use and reference. This database is fully compatible with the national irrigation geodatabase created by Ministry of agriculture, irrigation and livestock at national level.

\subsection{Preparation and Finalization of Maps}

Once the survey completed and data were transferred back to the consultant, all the maps for the irrigation canals were edited/corrected based on the corrections from the field. These maps along with other map elements (like legend, scale, logos etc) were printed at different visible scales as final maps and were handed over to MADERA. Some additional data like, the landcover atlas, topo maps, soils layers, DEM of the area and some other layers were also handed over to MADERA for better planning and implementation of current and future projects. 


\section{SUMMARY AND DISCUSSIONS}

Agriculture is the most important source of income for the households of the region (Bamyan and Maidan-Wardak provinces). In addition, the region is predominantly rural in nature thus the development of rural area is not possible without developing the agricultural sector and water is vital for both irrigated and rainfed agriculture in the area.

The terrain of the area is extremely mountainous with very little arable land available for cultivation. The population relies primarily upon subsistence farming with irrigated and rain-fed wheat, barley and potato being the main crops grown, supplemented with small scale livestock rearing. Agriculture productivity is low, with limited access of the population to seeds, technology and irrigation water.

Less than $50 \%$ of the population has access to land and this limits their ability to grow adequate food for their own consumption. Non-agricultural capabilities are very limited, which makes income diversification to other commercial activities difficult on the short run. There are high levels of unemployment and underemployment which contribute to increased food insecurity and growing poverty.

Total wheat productions for the year 2015-2016 for Bamyan and Maidan-Wardak provinces were 60.23 and 50.68 thousand metric tons respectively while total wheat required by the population living in these two provinces are 73.71 and 106.92 thousand metric tons (1000MT) calculated for $162 \mathrm{~kg}$ of wheat per head per year (wheat per capita, appendix V). In addition, as per wheat per capita consumption of $162 \mathrm{~kg} /$ year/head (FAOSTAT, 2016) both of these provinces are wheat deficient. The amount of wheat deficit in these two provinces are shown in table below:

\begin{tabular}{|c|c|c|c|c|c|c|}
\hline \multirow{2}{*}{ S No. } & \multirow{2}{*}{ Province } & $\begin{array}{c}\text { Total } \\
\text { Population }\end{array}$ & $\begin{array}{c}\text { Wheat per Capita } \\
\text { Consumption }\end{array}$ & $\begin{array}{c}\text { Total Required } \\
\text { Wheat }\end{array}$ & $\begin{array}{c}\text { Total Wheat } \\
\text { Production }\end{array}$ & $\begin{array}{c}\text { Deficit } \\
\text { Amount }\end{array}$ \\
\cline { 3 - 7 } & in persons & kg/head/year & in 1000MT & in 1000MT & in 1000MT \\
\hline 1 & Bamyan & 455,000 & 162 & 73.71 & 60.23 & -13.48 \\
\hline 2 & $\begin{array}{c}\text { Maidan- } \\
\text { Wardak }\end{array}$ & 606,000 & 162 & 106.92 & 50.68 & -56.24 \\
\hline
\end{tabular}

Table 1: Maidan-Wardak and Bamyan wheat deficit/surplus

Similarly, food security outlook of June, 2016 (Map1-FEWS NET) shows that some parts of Bamyan province come in stressed areas where food shortage can be an issue especially during winter months as shown in the following map: 


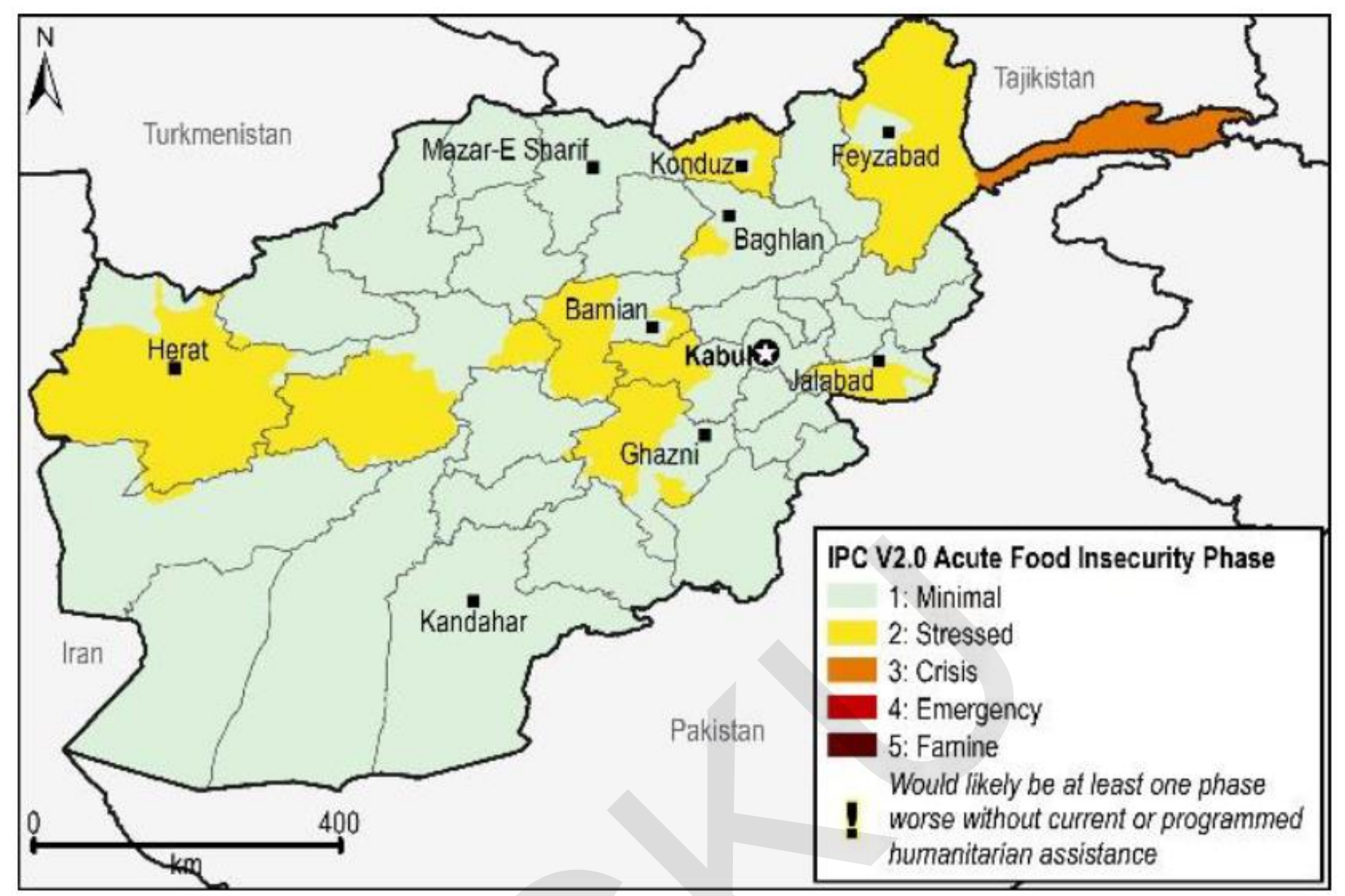

Map 1: Food Security Outlook June, 2016

\subsection{Landcover Comparison 1993 vs 2016}

Change detection is extensively used in proper distribution of natural resources and natural resource management, urban planning and many other fields. Fort this survey, Land cover data of 1993 and that of 2016 were compared which showed significant differences in some landcover types in the target districts.

The landcover change for Yakawlang district shows an increase in irrigated land while it shows a significant decrease in rainfed land, in addition, barren land has also increased may be due to the climate change (possibly due to the drought that hit whole Afghanistan from 1999 to 2001) as the water bodies and marshes has also shrunk significantly in the area. The rangeland from 1993 upto 2016 has significantly decreased mainly because of overgrazing and drought. Surprisingly the irrigated land has decreased and rainfed land has significantly increased in Hesa-e-Awal Behsud while rangeland and area under snow has shrunk to almost half.. Similarly, the irrigated agricultural land has decreased in Markaz-e-Behsud and so is rainfed land while barren land and rangeland has significantly decreased. The water bodies and marshland have significantly decreased throughout these years which impacted all other landuses. The summary of the comparison is presented in the following table: 


\begin{tabular}{|c|c|c|c|c|c|c|c|c|c|c|}
\hline District Land Cover Stat & tics (Hectar & & & & & & & & & \\
\hline District & $\begin{array}{l}\text { Irrigated } \\
\text { Ag. Land }\end{array}$ & $\begin{array}{l}\text { Rainfed } \\
\text { Ag. Land }\end{array}$ & $\begin{array}{l}\text { Fruit } \\
\text { Trees }\end{array}$ & $\begin{array}{l}\text { Barren } \\
\text { Land }\end{array}$ & $\begin{array}{l}\text { Forests } \\
\text { \& Shrubs }\end{array}$ & Rangeland & $\begin{array}{l}\text { Permanent } \\
\text { Snow }\end{array}$ & Built Up & $\begin{array}{l}\text { Water Bodies } \\
\& \text { Marshland }\end{array}$ & Years \\
\hline Yakawlang & $13,594.07$ & 924.77 & 30.13 & $29,341.41$ & 0.00 & $623,508.57$ & $4,941.39$ & 527.38 & $4,990.57$ & 2016 \\
\hline Yakawlang & $10,868.62$ & $3,511.50$ & $\mathrm{~N} / \mathrm{A}$ & $17,335.65$ & $\mathrm{~N} / \mathrm{A}$ & $966,595.27$ & $4,061.50$ & $\mathrm{~N} / \mathrm{A}$ & $5,038.58$ & 1993 \\
\hline Hesa-e-Awal-e-Behsud & $11,535.65$ & $3,962.79$ & 149.05 & 913.27 & 0.00 & $136,610.90$ & $3,257.29$ & 126.50 & 783.15 & 2016 \\
\hline Hesa-e-Awal-e-Behsud & $16,542.55$ & 751.34 & $\mathrm{~N} / \mathrm{A}$ & 23.00 & $\mathrm{~N} / \mathrm{A}$ & $208,099.20$ & $6,072.20$ & $\mathrm{~N} / \mathrm{A}$ & $\mathrm{N} / \mathrm{A}$ & 1993 \\
\hline Markaz-e-Behsud & $20,068.17$ & $17,134.81$ & 142.25 & $4,880.88$ & 0.00 & $285,614.60$ & $5,218.43$ & 418.15 & $1,012.40$ & 2016 \\
\hline Markaz-e-Behsud & $27,210.80$ & $20,399.70$ & N/A & $11,207.30$ & N/A & $423,565.12$ & $7,828.10$ & N/A & 320.40 & 1993 \\
\hline
\end{tabular}

Table 2: Landcover comparison of 1993 vs 2016

In addition, a total of 718 canals were identified in Hesa-e-Awal Behsud and Markaze Behsud and 317 canals were identified in Yakawlang district of Bamyan province, however, $853(82.5 \%)$ of all these canals were surveyed due to either inaccessibility or security concerns as advised by field offices. 


\section{OBSERVATION AND RECOMMENDATIONS}

1. The temporal comparison of the two landcovers for the years 1993 and 2016 showed, that irrigated area has increased and rainfed area has decreased

2. The amount of rangeland and barren land has decreased significantly in most of these areas

3. The two landcover comparison also shows, the marshland and water bodies in these areas has shrunk possibly due to climate change and increased use of water for irrigation

4. Main growing crops were wheat and potato in the project area

5. Average wheat yield (overall average of irrigated and rainfed wheat) was estimated as 1.89 and 2.08 tons/ha for Bamyan and Maidan-Wardak provinces respectively (APR, 2016)

6. Both Maidan-Wardak and Bamyan provinces are wheat deficit provinces of the country (Appendix III, wheat surplus and deficit provinces of Afghanistan)

7. Most of the canals were receiving their water from snowmelt (water harvested through small structures in the area e.g. ponds, bunds)

8. Some canals were receiving water from either spring or nawur

9. There are a total of 372 villages in Yakawlang, 776 in Behsud II and 361 villages in Behsud I districts respectively.

10. There were a total of 718 canals identified in Hesa-e-Awal and Markaz-e-Behsud while 317 canals in Yakawlang districts

11. Most of the villages in these districts are concentrated where land and water is available

12. As yield is very low in these areas, it can be increased through better water management and agricultural practices like laser leveling, lining canals, seed distribution etc

13. According to landcover atlas of Afghanistan, 2016, total irrigated areas are 13594.07, 11535.65 and 20068.17 ha for Yakawlang, Behsud I and Behsud II districts respectively

14. According to landcover atlas of Afghanistan, 2016, total rainfed areas are 924.77, 3962.72 and 17134 ha for Yakawlang, Behsud I and Behsud II districts respectively.

15. Wheat per capita consumption is calculated as $162 \mathrm{~kg} /$ person/year for Afghanistan (FAOSTAT)

16. The access to irrigated land is rather high in some areas though one would have to look at the quality and nature of irrigation (seasonal versus perennial) and the size of landholdings. 


\section{APPENDICES}

Appendix I: Amount of irrigated area and no of teams for each district

\begin{tabular}{|c|l|l|c|c|c|}
\hline S No. & Province & \multicolumn{1}{|c|}{ District } & Irrigated Agric Land (ha) & No of teams & No of Supervisors \\
\hline \hline 1 & Bamyan & Yakawlang & 13,563 & 3 & 1 \\
\hline 2 & Maidan-Wardak & Markaze Behsud (II) & 20,000 & 4 & 3 \\
\hline 2 & Maidan-Wardak & Hesa Awal Behsud & 11,521 & 3 & 2 \\
\hline & & & & & \\
\hline
\end{tabular}

Appendix II: Irrigation Field Survey Questionnaire (Dari)

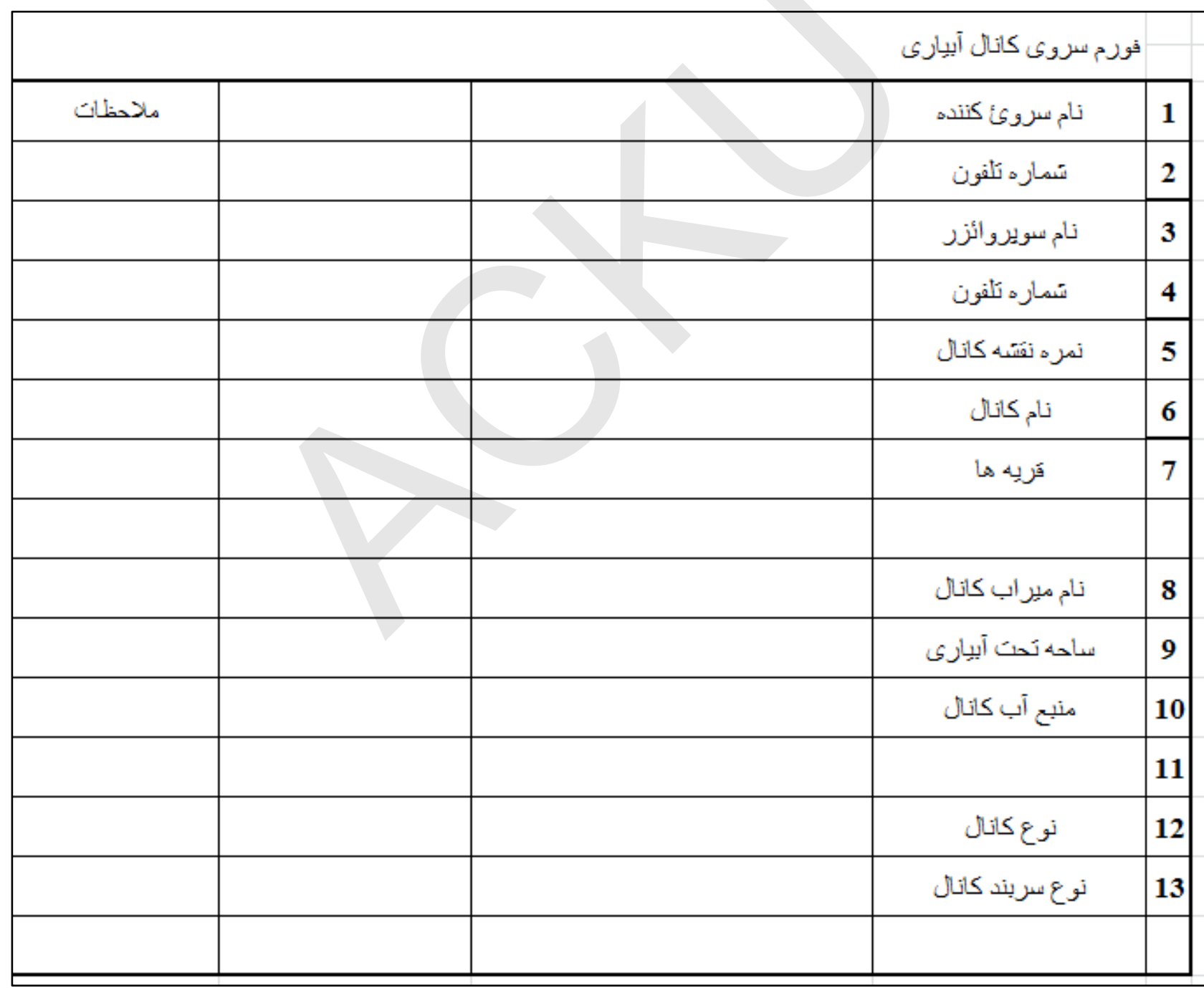


Appendix III: Wheat deficit and surplus provinces of Afghanistan

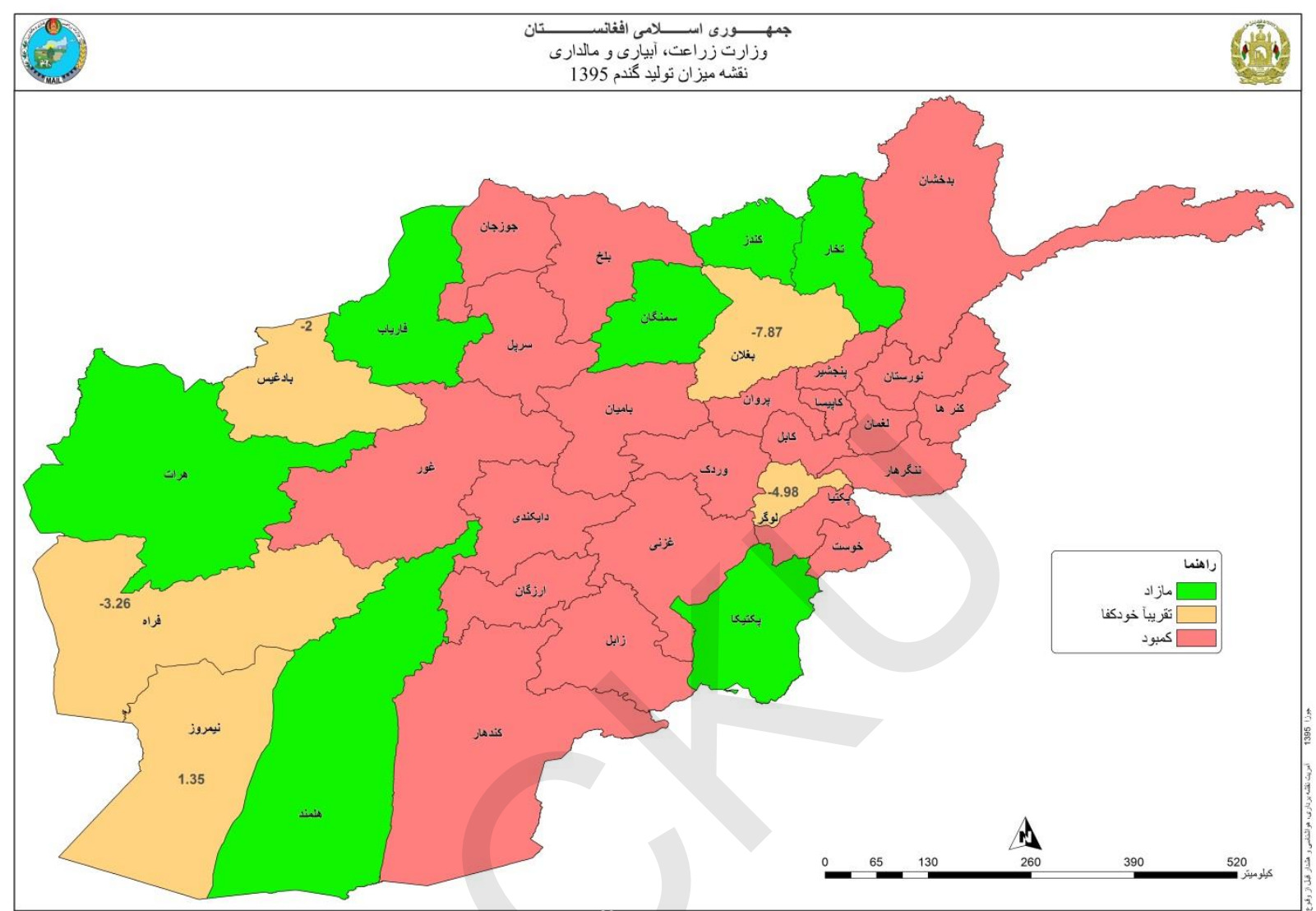


Appendix IV: Field Surveyor's TOR

\section{Field surveyors TOR}

\section{Background:}

MADERA is an international organization, active in AFGHANISTAN since 1988, promoting rural development and support to village communities. MADERA's actions are directed towards capacity building and initiatives which enable local communities to lead and manage the development of their territory. MADERA promotes, in collaboration with other partners, a participatory and community approach to development, developing with the population "integrated" programs which aim to take into consideration the diversity of their needs.

\section{Overview of the program:}

MADERA, GERES and Solidarités International, three French NGOs working in Afghanistan, have come together to implement a $31 / 2$ year program, funded by the French development agency (AFD). The aim of the program is to increase the living standards and quality of life for the rural population of the Central Highlands region, through the promotion of rural development and natural resources management.

\section{Main Responsibilities:}

The field surveyor will work under the GIS survey team leader to collect all the information on irrigation canals of the assigned area using a proforma, handheld GPS and a digital camera where possible. He will work in a group of two and will report and handover his work to the GIS team leader on daily basis for review and validation. His/her duties will be as follows:

- Accurately track all the canals and their command areas, by walking through the length of canal, using a handheld GPS and digital camera etc

- Edit and correct the hardcopy maps according to the field conditions

- Accurately record field data into the proforma 
- Collect the name of mirab, how much area is being irrigated, what kinds of crops are grown in the command area, what villages they (the canals) serve and who funded construction or rehabilitation of this canal (if any)

- Any other information required by the project survey team

Qualifications:

- University student or recent graduate (Preferably from agriculture, geoscience faculties or any other relevant field)

- Good interpretation and recording skills

- Willingness to travel and walk through each irrigation canal in Behsud I, Behsud II and Yakawlang districts of Wardak and Bamyan provinces respectively

- Ability to understand, explain, and use field GIS maps of the area

- Ability to use a handheld GPS and digital camera

- Prior working experience in such surveys

To Apply: Please send your CVs and cover letter to or bring your hardcopy applications in person to 
Appendix V: Glimpses from the field survey
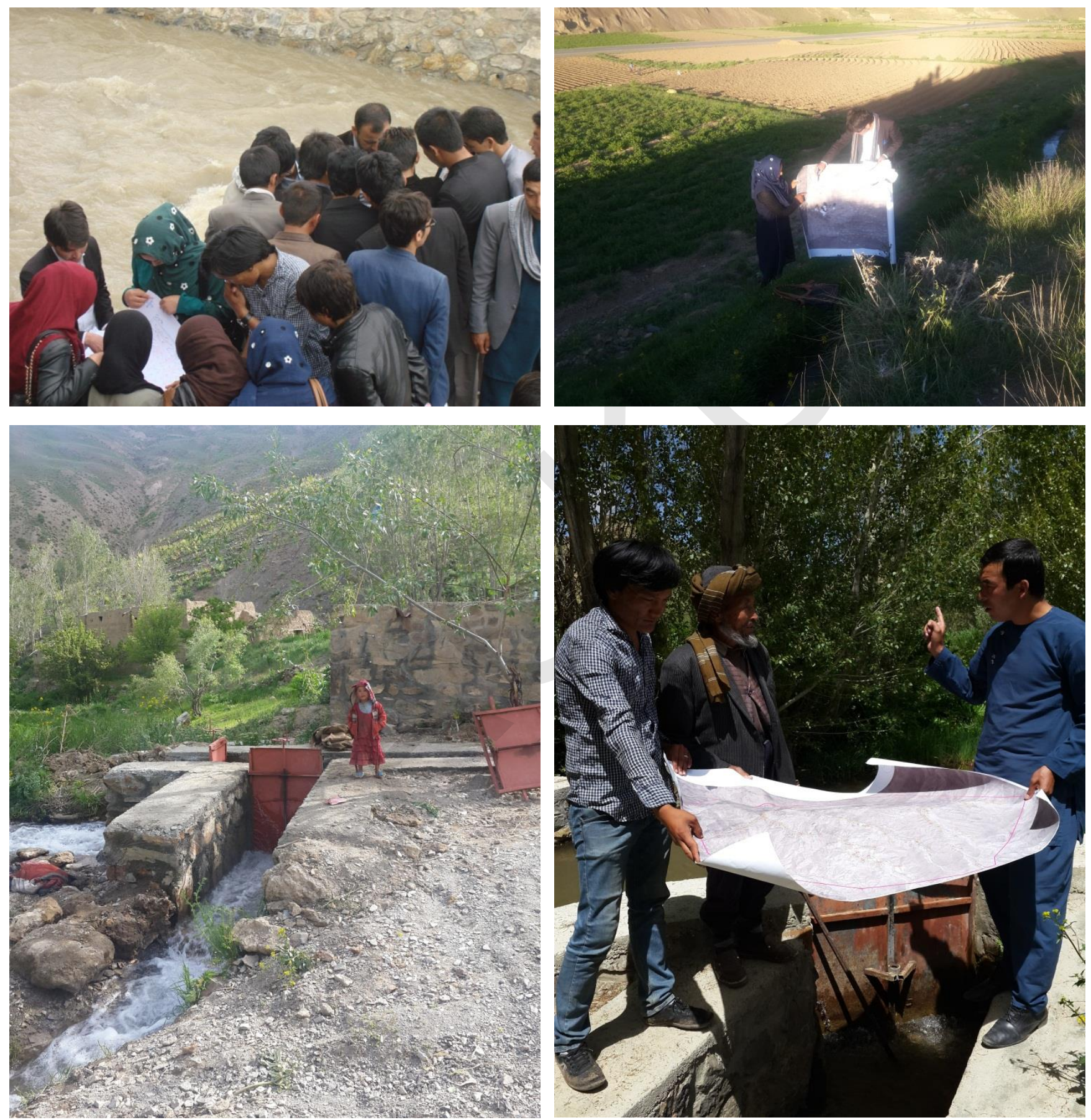

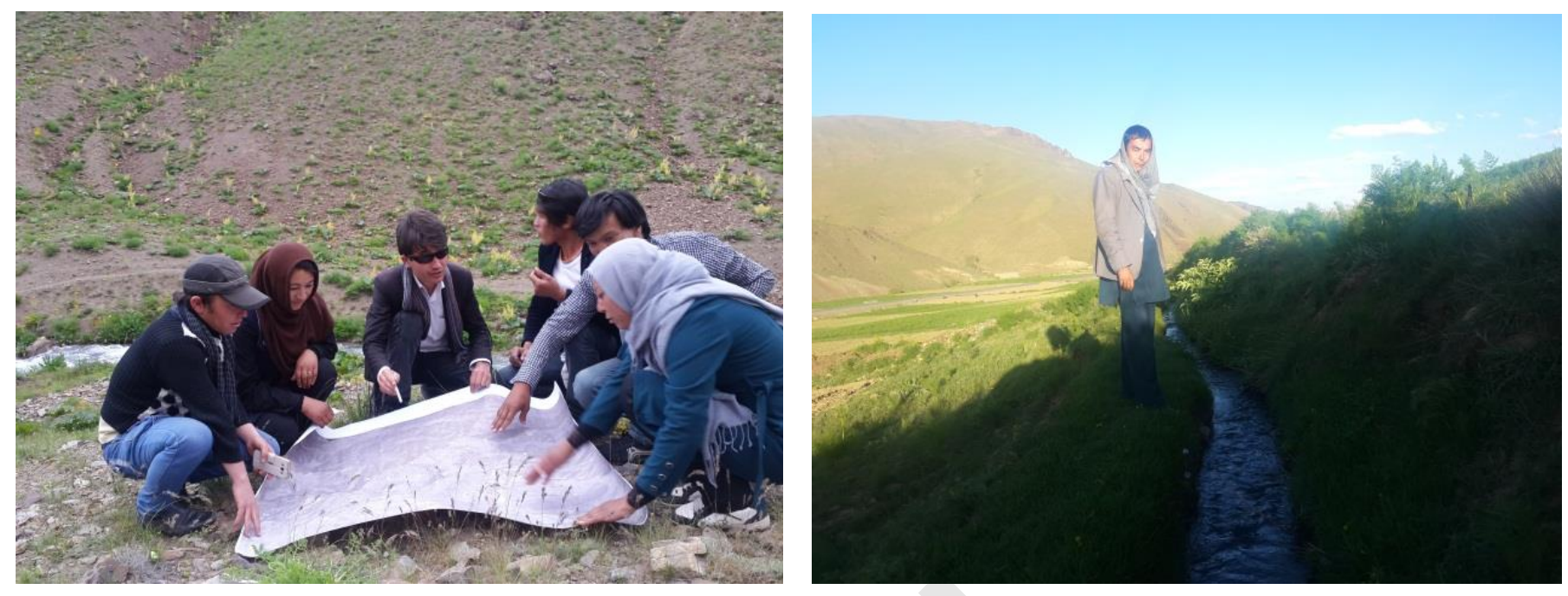
Appendix VI: Wheat per capita consumption of Afghanistan and other regional countries

\begin{tabular}{|c|c|c|c|}
\hline \multicolumn{4}{|c|}{ Wheat Consumption Per Capita (kg/capita/yr) } \\
\hline & \multicolumn{3}{|c|}{ year } \\
\hline \multirow{14}{*}{ country } & & item & 2011 \\
\hline & Afghanistan & wheat & 161.9 \\
\hline & Indonesia & Wheat & 23.5 \\
\hline & Iran (Islamic Republic of) & Wheat & 152.3 \\
\hline & Kazakhstan & Wheat & 94.4 \\
\hline & Kyrgyzstan & Wheat & 138.0 \\
\hline & Malaysia & Wheat & 52.4 \\
\hline & Pakistan & Wheat & 113.8 \\
\hline & Russian Federation & Wheat & 130.8 \\
\hline & Tajikistan & Wheat & 127.9 \\
\hline & Turkey & Wheat & 173.5 \\
\hline & Turkmenistan & Wheat & 188.1 \\
\hline & Ukraine & Wheat & 106.0 \\
\hline & Uzbekistan & wheat & 170.6 \\
\hline
\end{tabular}




\section{REFERENCES}

- $\quad$ FEWS NET, June 2016, food security outlook.

- Ministry of Agriculture, Irrigation and Livestock, June 2016, agricultural prospect report (APR).

- Afghanaid, 2015, integrated natural resource management report.

- Solidarite', Food security assessment in Afghan rural areas, Yakawlang, Afghanistan

- USAFCCC (United State Air Force Combat Climatology Center), 2003. Bamyan, Afghanistan - Full Year Climatology. United State Air Force Combat Climatology Center, Asheville, North Carolina.

- Shobair, S.S., 2002. Current Drought Situation in Afghanistan. Unpublished report. Food and Agriculture Organization (FAO), Afghanistan.

- ASAP, 2008, Bamyan province agricultural profile.

- AMMC/JICA, 2010, Survey on agricultural and rural development potential in the central highlands of Afghanistan.

- GRM, Regional rural economic regeneration strategies, provincial profile for Wardak province. 